Vedecký prispevok/ Scientific Article

Recenzované/ Review: 29. 11.2021

https://doi.org/10.24040/eas.2021.22.2.33-50

\title{
Dependent self-employment - Italy as a good practice example
}

\section{Závislé podnikanie - Taliansko ako príklad dobrej praxe}

\section{Miroslava Knapková}

Abstract: The aim of the paper is to describe dependent self-employment phenomenon on the example of selected EU country - Italy. In Italy, not only hybrid category of dependent selfemployment is officially recognised and legally regulated, but also specific social protection is offered to dependent self-employed persons. Content analysis of relevant literature and legal documents was used to identify specifics of dependent self-employment in Italy. Results indicate that in Italy, regulation of dependent self-employment has undertaken remarkable changes in the past years. The latest labour market reform (Jobs Act) subsumed the most typical forms of dependent self-employment (contracts for "coordinated and continuous collaborations" and contracts based on specific projects) under the protection of Labour law regulation. Despite the persisting controversial attitudes towards this situation, the view of the positive trend in the development of dependent self-employment legislation in Italy prevails.

Key words: Dependent self-employment. Social protection. Legal regulation. Italy. Good practice.

JEL Classification: L26. E24. J21.

\section{Introduction}

One of the important decisions of natural persons is the choice about how to get their income. The gainful activity includes the performance of dependent work in an employment relationship and the performance of self-employed activity in the form of entrepreneurship or other gainful self-employed activity. A special phenomenon of the latest period is an activity, which fulfils the features of both dependent work and self-employment.

In several EU countries, labour law also regulates the persons who are self-employed and, at the same time, economically dependent on a quasi-employer. These persons are not typical entrepreneurs because they do not perform a gainful activity on their own and for the purpose of profit. Because of the absence of personal subordination of the persons and quasi employer, 
these persons could not be considered as employees (performing dependent work). On the other hand, the activities of these persons do not meet legal characteristics of business activities as defined by the Commercial Code or the Trade Licensing Act in Slovakia.

These persons are not in relation to the quasi employer (de facto business partner) based on an employment contract, even if they perform work in a way similar to employees, i. e. on a contractual basis, at a certain agreed workplace, and within agreed working hours. In the legislation of several foreign countries, this category of natural persons is a subject matter to certain level of labour and social security protection (Barancová and Schronk, 2018). This category of persons is on the border between the employee and the legal status of self-employed entrepreneur. It is a model of a hybrid "quasi-employee", working for the employer.

Dependent self-employed person is a person whose job activities are on the border between dependent employment (which means activity of employee performed for employer under the employment contract) and independent entrepreneurial activities (which a natural person - an entrepreneur - performs on their own name and on their own responsibility, according to the business or civil contract). This term includes those situations when a person performs de jure independent entrepreneurial activity, but de facto they depend on one committer.

In the European Union, there are heterogenous attitudes of member states to the status and regulation of the dependent self-employment. According to the "Tackling Dependent and Bogus Self-Employment" report (2016), there are countries in the EU that do not recognise dependent self-employment at all. On the other hand, there are EU countries, that not only recognise status of dependent self-employment, but also extend social protection to the specified categories of the dependent self-employed, even though they are not presumed to be employees. These countries include Denmark, France, Germany, Greece, and Italy.

Italy is so far the only country in the European Union that has moved from recognising the status of dependent entrepreneurs to regulating their social protection, to bringing this form of business fully under the protection of the Labour Code. The example of Italy demonstrates how dependent self-employment regulation could also be approached in other countries.

The aim of the paper is to identify specifics of dependent self-employment regulation and social protection, based on the examples of Italy. The main motivation of the article is to point to the good practice example of Italy, mostly because Slovakia is one of those EU countries that do not legally regulate and support dependent self-employment (even if it is a part of Slovak business environment, as so called "zamestnanie na živnost"). Without official recognition of the category of dependent entrepreneurs, it is impossible to ensure their adequate legal and social protection, it is difficult to provide them with targeted state assistance (e.g., financial 
one), and it is impossible to collect statistical data on dependent entrepreneurs in an official way.

The desk research analysis based on the available literature, content analysis of legal documents, and secondary statistical data processing were used to elaborate the paper. The article provides no original quantitative data. Its contribution is in providing diverse perspectives on the issue of dependent self-employment and in systematic summary of the evolution of protecting dependent entrepreneurship in Italy.

The article consists of four parts. In the first one, theoretical approaches to dependent selfemployment from the European perspective is summarised. The second part describes materials and methods used for the analysis. In the third part of the article, the author provides results, discussion and systematic information on specifics of dependent self-employment legal regulation and social protection in Italy. In the conclusion, the research implications, research limitations and future directions for continuing research are discussed.

\section{Dependent self-employment in the European Union}

Dependent self-employment is a relatively new term in all the European Union countries. At the European level, the issue of dependent self-employment was addressed in the report for the European Commission by Supiot (2001). The report described self-employed persons that are "economically dependent on the payer" and in "permanent legal subordination" to their payer, with Supiot arguing that "those workers who cannot be considered as employees but are in a situation of economic dependence on the payer should be able to exercise social rights, thanks to this dependence ". In the The Future of Work study (OECD, 2019), the OECD argues that there has been an increasing number of jobs at a borderline between the employment and self-employment, including suppliers who work in a dependent relationship with only one company and who have as little autonomy as employees, even if they are classified as selfemployed. This phenomenon was supported (eventually highlighted) during the economic crisis (Muehlberger, 2007). In Europe, dependent self-employed person is formally understood as a self-employed person who usually carries out his activity based on a contract concluded with one contracting authority, on which he is then practically wholly or largely dependent on income (Pedersini, 2020).

The dependent self-employment (OECD, 2019; Supiot 2001) can be considered as part of the general trend of increasing labour market flexibility. Due to the structural, technological, and demographic changes, as well as lifestyle changes, non-traditional employment relationships, such as dependent self-employment or part-time work, have become increasingly 
important (Knapková, 2017; Bozzon and Murgia, 2021; Karlsson, 2019). On the other hand, the formalisation and bureaucracy of the work in the workplace (Seková and Václavíková, 2015) and the rigidity of legal regulations (Campos et al., 2018) prevent putting adequate changes in practice. The problem of dependent self-employment is related to the flexibility of labour market, the issue of undeclared work, and the expanding use of the so-called "švarc" system (false self-employment) (Dvouletý, 2017; Nikulin, 2021; Williams and Horodnic, 2019). Most of these areas, especially the area of hidden employment, are problematic mainly because of increasing social dumping (ILO, 2010).

According to the "Social protection rights ..." study (Eichhorst, et al., 2013), there are only a few countries in European Union, in which "hybrid" category of dependent self-employment is legally allowed. These countries include Austria (regulates free service workers, new selfemployed workers and contractors of work and services), Germany (free service contract workers), and Italy (contracts of continuous and coordinated collaboration and contracts for a project). In the United Kingdom, dependent self-employed workers are also a legally recognised category (the author points to this fact even that the UK is not part of the EU anymore). Boheim and Muehlberger (2006) state that in British legislation there is a legally regulated status of employee (individual who is working under the contract of employment), status of employed person (individual who is working personally under any other contract) and status of the worker (individual who agrees to personally carry out work under the contract, without running a business of his own). Another country, where status of economically dependent self-employed workers is legally recognised, is Spain (Garcia and Gonzales, 2012).

Definition of dependent self-employed person was provided by the "Social protection rights ..."study (Eichhorst et al., 2013). According to him, dependent self-employment is "a working relationship where the worker is formally self-employed yet under conditions of work like those of dependent employees“. Although not all European Union countries consider economically dependent self-employment as a serious problem that needs to be legally regulated, in 2011 European Economic and Social Committee reported the need to discuss economically dependent self-employed persons in the whole European Union (Opinion of the European Economic and Social Committee, 2011). In the report, Committee offered several suggestions about how to cope with this phenomenon. It is necessary to focus mostly on the economic and social rights of the economically dependent self-employed workers. In most of the European countries, employees are specially protected under the working contract. This kind of protection is not guaranteed to persons performing work under the business contract (such as relationship between natural person - entrepreneur and company). Because natural 
person performing economically dependent self-employed work is on the border between the employee and independent entrepreneur, Committee recommended to protect such a person by at least part of the rights that are standardly applied to employee. However, there is still a problem, that there are only few countries in the European Union that legally accept status of economically dependent self-employed person (such as Italy, Germany, Austria, Spain, Portugal). Based on the recommendation of Committee, a number of studies focusing on the European Union countries have highlighted the inadequacy of national legislation in defining and consequently protecting dependent entrepreneurs (Ludera-Ruszel, 2017; Spasova and Wilkens, 2018; Riesco-Sanz, 2019; Giraud and Lechevalier, 2018). The lack of examples of good practice (i. e. European Union countries that have taken a serious approach to regulating and dealing with the situation of dependent entrepreneurs) make it difficult to compare legislation, social protection and, consequently, statistical data on dependent entrepreneurs across Europe. In the subsequent analysis, the author focuses on Italy, which is, so far, the only European Union country that has recognised the status of dependent entrepreneurs, brought them under the protection of the Labour Code and granted them social protection similar to that of employees.

\section{Material and methods}

Dependent self-employment is a phenomenon with a growing influence on the business environment, labour market, lives of individuals, families, and the whole society. To address the issue of dependent self-employment in Slovakia, it is useful to understand specifics of the phenomenon on the example of those countries, which have already undertaken steps for legal and social acceptance of the dependent self-employment. The aim of the paper is to describe dependent self-employment phenomenon on the example of the selected EU country - Italy. More specifically, the following objectives are addressed in the article:

1. to analyse the historical development of the acceptance and legal regulation of dependent self-employment in Italy,

2. to identify current areas of social protection of dependent self-employed persons in Italy.

The desk research analysis based on the available literature, content analysis of legal documents, and secondary statistical data processing were used to elaborate the paper. The situation in Italy was evaluated in historical perspective (covering the period from 1995 until present), with the deep focus on the status of those professions, which are considered on the border between employment and self-employment. The legislation issued within the examined period was analysed to generate an overview of the legal regulation of dependent self- 
employment in Italy. The article presents those outcomes that provide the basic picture of the 'state of the art' in Italy.

\section{Results and discussion}

In this part of the article, the author provides results divided into two subsections, linked with two specific objectives of the article. In the first subsection, development of the legal regulation of dependent self-employment is analysed (in historical context, with the focus on progressive increase in the scope of regulation). In the second subsection, the analysis of the current social protection of dependent self-employed persons in Italy is provided.

\subsection{Regulation of dependent self-employment in Italy in historical context}

In Italy, the self-employed persons (lavoratori autonomi) are those persons who provide a service or work for remuneration without being subordinate, and work with their own means of work (Meliciani and Radicchia, 2005). They do not receive a wage and are not subject to social protection associated with paid work (Lassandari, 2019). They are excluded from the main acts of employment protection - Job Act no. 81, issued on 22 May 2017 and effective since 13 June 2017.

In addition, in Italy, there are so-called liberi professionisti (status similar to freelancers), which is a group that includes self-employed persons from the liberal professions (lawyers, notaries, architects, doctors, journalists, etc.; Mariotti and Akhavan, 2019), as well as persons practicing professional freelance activities (Razzolini, 2021). Licensed workers (i.e. professionals whose practice is subject to a state examination and registration with a professional association) generally have their own private, professional, social security and insurance schemes for maternity leave (albeit to a limited extent), incapacity for work and pension (Pedaci et al., 2017; Raitano, 2018). However, they are excluded from collective and company agreements, working time regulations, protection in the event of a company's insolvency, holiday provisions and equal treatment regulations.

Traditional categories of self-employed persons and freelancers may be dependent on business partners or clients. According to the Italian Labor Force Survey, almost 1 in 4 freelancers work for a single client, most of whom declare that they have limited management autonomy (Ranci, 2012). In the last 20 years, the spread of "non-standard" forms of work has been growing, the characteristics of which differ from the characteristics of employment for an indefinite period (Picot and Menéndez, 2019). Among these non-standard forms, there is a "semi-subordinate" employment relationship, which combines the conditions typical for 
subordinate dependent activity with the conditions typical for self-employment (Borghi et al., 2018). According to Ranci (2012), 83\% of semi-subordinate contracts with self-employed persons involve a relationship with one client; it is up to $90 \%$ if only casual work is considered.

Since the mid-1990s, several reforms in Italy have introduced new types of contracts on the border between the self-employment and traditional dependent activity. In 1995, a new type of a short-term contract called a "continuous and coordinated contractual relationship" (Co.co.co) was introduced (Del Conte and Gramano, 2017). Pension contributions have been introduced for Co.co.co contracts to be paid into a special fund within the social security administration (Pedaci et al., 2017). Under these contracts, the worker is (at least theoretically) independent because there is no formal subordination to the employer. The worker is a partner whose activity must be adapted to the organizational needs of the company (Tealdi, 2012). The company pays lower social security contributions in connection with standard contracts for an indefinite period, while workers in Co.co.co contracts are entitled to (lower) social security benefits (Pedaci et al., 2017; Gramano and Gaudio, 2019).

In order to restrict the use of Co.co.co., the Act no. 30/2003 ("Biagi's Reform") introduced a project contract (Co.co.pro) as a form of "false self-employment" (Pinelli et al., 2017). This type of employment must be linked to a specific project selected by the work provider. The possibility to work based on a project contract was further extended beyond professional and artistic activities, which additionally enabled manual and non-professional workers to supply work (Borghi and Murgia, 2019). All such workers receive family benefits and allowances during parental leave, as well as during hospital stays, although social security benefits are less generous than in the case of fixed-term employment contracts (Spasova et al., 2019).

Act no. 30/2003 also introduced the notion of "casual workers", and regulates occasional independent activities performed during a period that cannot exceed 46 days in the same year with the same employer/contractor (Ranci, 2012). In addition, the maximum annual income under this type of contract must not exceed EUR 5 000. Occasional work does not require the payment of social security contributions (Garmero, 2018).

Italian companies have "employed" various categories of self-employed workers in the last decades. The aim of these quasi-employment relationships was to ensure a more flexible contract for the employer/contractor (speed and ease of concluding the contract) and the worker (determination of time and methods of work) (Eichhorst and Marx, 2015). However, these contracts have also been used by both the public and private sectors as a low-cost alternative to fixed-term employment contracts, as they were not the object of employment and social security legislation (Muehlberger, 2007). 
In 2012, there was a significant reform of dependent self-employment in Italy. Act no. 92/2012, the so-called "Fornero Reform", regulates any self-employment work activity with an assigned VAT ID (Pinelli et al., 2017). A dependent self-employment is a "coordinated and continuous relationship" which creates an employment relationship (with the burden of proof on the employer), if at least 2 of the following conditions are met:

a) the relationship lasts for more than eight months in the same year,

b) the income from the employment relationship represents more than $80 \%$ of the total income received by the worker during the year,

c) the contractor created a workplace for the worker in the contractor/employer's premises (Del Conte and Gramano, 2017; Perulli, 2020).

The process of legal regulation of dependent self-employment was completed in 2015, by adopting the Legislative Decree no. 81/2015, The Labour Contracts Code (so-called JACode, or Jobs Act). It was part of the Renzi government labour market reform (Gilli et al., 2015). The enabling law (Law 183/2014), giving mandate to the Government to fully implement the Jobs Act during the summer of 2015, entered into force on 16th December 2014. As of September 2015, the Italian Government has completed the implementing process of the Enabling Law. All the provisions were published in the Official Journal and thus have become effective. As part of the enabling law, the following decrees were adopted in Italy:

- Legislative decree 23/2015, reforming employment protection legislation for permanent contracts,

- $\quad$ Legislative decree $22 / 2015$, redesigning the system of unemployment benefits,

- Legislative decree 80/2015, including measures to reconcile work and family life,

- Legislative decree $81 / 2015$, reorganising the typology of labour contracts,

- Legislative decree 148/2015 reforming wage supplementation schemes ('Cassa integrazione guadagni’),

- Legislative decree 149/2015, reforming inspection activities,

- Legislative decree 150/2015, reforming and strengthening active labour market policies,

- Legislative decree 151/2015, including simplification measures and other dispositions concerning equal opportunities

As of 1 January 2016, the provisions governing subordinate work shall also apply to collaborative relationships (Cherry and Aloisi, 2016; Seghezzi and Tiraboschi, 2018), that take the form of exclusively personal, continuous work, the execution methods which are organized by the client, including the terms of the timescales and the place of work (Article 2, 
paragraph 1). These legislative interventions are aimed at extending labour protection to independent workers whose personal activity is organised by the client.

Adoption of the Jobs act and subsumption of the contracts for coordinated and continuous collaborations (co.co.co), as well as those based on specific projects (co.co.pro) under the protection of Jobs act (therefore under the dependent work), are considered controversial in both Italy and around the world. Several studies as well as court decisions point to the necessity to distinguish between the voluntary decision of a worker to perform work on the basis of co.co.co and co.co.pro contracts, and that is why they require their independence (even without appropriate social protection) (Aloisi, 2018; Pallini, 2019; Borghi and Murgia, 2019). As stated by Del Conte and Gramano (2017), some dispositions recall those protections already provided for employees (for example, the suspension of the relationship on request of the worker in the event of illness, pregnancy, accident); on the other hand, some rules focus on protecting the economic, social and contractual position of the independent contractors in the marketplace.

Contrastingly, increasing social protection of dependent self-employment is considered an example of progressive legislation. As formulated by Gramano and Gaudio (2019), there should be a continuous trend of enlarging the scope of application of labour laws to apply certain traditional labour rights not only to employees but also to certain types of independent contractors.

\subsection{Social protection of dependent self-employed persons in Italy}

The Italian legislator decided to explicitly define the category of economically dependent workers (so-called parasubordinati) as those who perform a "continuous, coordinated and mainly personal" form of collaboration with the same employer (Art 409 N.3, Codice di Procedura Civile). For the parasubordinati, the legislation provides levels of social protection similar to those guaranteed to dependent workers and they are also entitled to be represented by trade unions in collective bargaining ((Tackling Dependent and Bogus Self-Employment, 2016).

As stated by Spasova et al. (2019), self-employed persons in Italy do not have access to unemployment protection. However, dependent self-employed persons are protected against unemployment in the same way as employees. Based on the current system of social protection of self-employment in Italy (MISSOC, Italy, 2021), the categories of self-employed, registered with the separate pension scheme (Gestione Separata), are considered as the "new" selfemployed (as opposed to the traditional forms of self-employed, such as farmers, craftsmen and tradesmen). The 2015 labour market reform made a clear difference between occasional 
business relationships on a sub-contracting basis, which are assimilated to self-employment (so called "new" type of self-employed), and continued collaboration and repeated work (co.co.co also called para-subordinati) relationships with the same sub-contractor, which are assimilated to employment. The new self-employed who are registered and pay contributions under the separate pension scheme (Gestione Separata) are:

- occasional business relationship without contractual subordination (as per law no. $326 / 2003$ ) whose annual income is above $€ 5,000$ (co.co.co.),

- door-to-door sellers whose annual income is above $€ 5,000$ (co.co.co.),

- administrators, statutory auditors, companies' associations, and other bodies' auditors, with or without legal status, company liquidators,

- $\quad$ associates of newspapers, magazines, encyclopaedia, and the like,

- board and commission fellow members,

- professionals, who do not have a private ad hoc scheme and have a VAT registration number (they pay $25.98 \%$ of their pensionable annual income).

Apart from this, private ad hoc funds exist for a certain number of liberal professions (Casse dei liberi professionisti, such as medical doctors, architects, engineers, etc.).

In the following table, there are data on the level of social protection of dependent selfemployed persons in Italy (namely para-subordinates, or co.co.co. workers).

Table 1 Social protection of dependent self-employed persons in Italy

\begin{tabular}{|c|c|}
\hline $\begin{array}{c}\text { Area of } \\
\text { protection }\end{array}$ & Method of application for "new" self-employed \\
\hline \multicolumn{2}{|r|}{ Sickness cash benefits } \\
\hline Coverage & $\begin{array}{l}\text { Sickness in case of hospitalisation and sick leave for specific categories } \\
\text { of "new" self-employed registered under the separate pension scheme } \\
\text { (Gestione Separata) is granted based on certain conditions }\end{array}$ \\
\hline Financing & $\begin{array}{l}\text { A monthly contribution of } 0.72 \% \text { calculated as a percentage of earnings } \\
\text { with a lower and higher ceiling: minimum pensionable annual income }= \\
€ 15,953 \text {; maximum }=€ 103,055-\text { in } 2021)\end{array}$ \\
\hline $\begin{array}{l}\text { Benefits/services } \\
\text { (amounts, } \\
\text { duration, co- } \\
\text { payments) }\end{array}$ & $\begin{array}{l}\text { Duration: } \\
\text { - Sick leave (indennità di malattia): it may not exceed } 1 / 6 \text { of the insured } \\
\text { working days per calendar year with a minimum duration of the leave ( } 4 \\
\text { days) and a maximum of } 61 \text { days per year ( } 180 \text { days in case of cancer or } \\
\text { chronic illness treatments). } \\
\text { - Hospitalisation (degenza ospedaliera): maximum duration of } 180 \text { days } \\
\text { per year. Amount: } \\
\text { - Sick leave: calculated in accordance to record of monthly } \\
\text { contributions translated as different percentage rates of } € 282.34 \\
\text { - Hospitalisation: (percentage rates applied for sick leave are doubled) }\end{array}$ \\
\hline $\begin{array}{l}\text { Taxation and } \\
\text { social }\end{array}$ & $\begin{array}{l}\text { Where benefits are granted to the "new" self-employed the same tax } \\
\text { regime applies as for employees. }\end{array}$ \\
\hline
\end{tabular}




\begin{tabular}{|c|c|}
\hline $\begin{array}{c}\text { Area of } \\
\text { protection }\end{array}$ & Method of application for "new" self-employed \\
\hline $\begin{array}{l}\text { contributions on } \\
\text { benefits }\end{array}$ & $\begin{array}{l}\text { Where the "new" self-employed are entitled to sickness cash benefits, } \\
\text { the sick leave is covered by deemed contributions as it applies to the } \\
\text { employees. }\end{array}$ \\
\hline \multicolumn{2}{|r|}{ Maternity/paternity } \\
\hline Coverage & $\begin{array}{l}\text { Maternity/Paternity (with special regulations, in relation to cash benefits) } \\
\text { is covered under the traditional self-employed special scheme of the } \\
\text { General Compulsory Insurance (AGO), as well as under the separate } \\
\text { pension scheme (Gestione separata). Legislative Decree } n^{\circ} 80 / 2015 \\
\text { introduced the paternity benefit for self-employed in case of single } \\
\text { parent. }\end{array}$ \\
\hline Financing & $\begin{array}{l}\text { Monthly contribution is calculated as a percentage of earnings with a } \\
\text { lower and higher ceiling (minimum pensionable annual income }= \\
€ 15,953 \text {; maximum }=€ 103,055 \text { in } 2021 \text { ). }\end{array}$ \\
\hline $\begin{array}{l}\text { Conditions for } \\
\text { access to } \\
\text { benefits/services }\end{array}$ & $\begin{array}{l}\text { For traditional self-employed and new self-employed: For maternity } \\
\text { benefits in kind, no distinction is made between self-employed and } \\
\text { employees. } \\
\text { "New" self-employed under the separate pension scheme (Gestione } \\
\text { separata) must have completed at least } 1 \text { month of contributions within } \\
\text { the } 12 \text { months prior to the beginning of the maternity leave or, in case of } \\
\text { adoption, prior to the commencement of adoption. } \\
\text { Additional benefits: } \\
\text { - State financed Maternity allowance (Assegno di maternità dello Stato) } \\
\text { is simply conditional upon regular registration with the relevant Special } \\
\text { Pension Fund. } \\
\text { - Maternity allowance financed by the municipalities (Assegno di } \\
\text { maternità dei Comuni) is means-tested (granted against an ISEE value of } \\
€ 17,416.66 \text { for 2021) }\end{array}$ \\
\hline $\begin{array}{l}\text { Benefits/services } \\
\text { (amounts, } \\
\text { duration, co- } \\
\text { payments) }\end{array}$ & $\begin{array}{l}\text { The benefit's amount is } 80 \% \text { of effective average daily income timed by } \\
\text { the number of days of maternity leave's total duration. }\end{array}$ \\
\hline \multicolumn{2}{|r|}{ Invalidity } \\
\hline Coverage & $\begin{array}{l}\text { Invalidity is covered under the self-employed special scheme of the } \\
\text { General Compulsory Insurance (AGO), as well as under the separate } \\
\text { pension scheme (Gestione separata). }\end{array}$ \\
\hline Financing & $\begin{array}{l}\text { Contributions are calculated as a percentage of the pensionable annual } \\
\text { income with a lower and higher ceiling: minimum pensionable annual } \\
\text { income in } 2021 \text { is up to } € 15,953 \text { and maximum is } € 78.965,00 \\
\text { Different rates of contributions apply to "new" self-employed under the } \\
\text { separate pension scheme (Gestione separata): } \\
\text { - } 24 \% \text { for self-employed already insured under another compulsory } \\
\text { management scheme or already retired ( } 0.72 \% \text { of which covering } \\
\text { sickness, maternity and family benefits); } \\
-25.98 \% \text { for "new" self-employed with VAT registration number } \\
(0.72 \% \text { of which covering sickness, maternity and family benefits, and } \\
0.26 \% \text { of which covering the risk of partial loss of income); }\end{array}$ \\
\hline
\end{tabular}




\begin{tabular}{|c|l|}
\hline $\begin{array}{c}\text { Area of } \\
\text { protection }\end{array}$ & \multicolumn{1}{|c|}{ Method of application for "new" self-employed } \\
\hline & $\begin{array}{l}\text { - 33.72\% for "co.co.co" (para-subordinate workers) }(0.72 \% \text { of which } \\
\text { covering sickness, maternity and family benefits, while there is no } \\
\text { coverage against the risk of unemployment) } \\
-34.23 \% \text { for "co.co.co" }(0.72 \% \text { of which covering sickness, maternity } \\
\text { and family benefits and } 0.51 \% \text { of which covering the risk of } \\
\text { unemployment (DIS-COLL). }\end{array}$ \\
\hline
\end{tabular}

Source: own elaboration based on MISSOC, Italy, 2021

\section{Conclusions}

Lack of information about the self-employed persons dependent on one payer (employer), insufficient legal regulation of their status in many European Union member states, and different definition of dependent self-employment make it difficult to provide statistical records about this group of persons. In Slovakia, there is no official recognition of the dependent selfemployment category. However, the so called "zamestnanie na živnost" (trade authorisation employee) is a standard part of Slovak labour market relations (in the voluntary as well as forced forms). To understand principles and specifics of legal regulation of dependent selfemployment (Eichhorst et al., 2013; Boheim and Muehlberger, 2006; Borghi and Murgia, 2019), the author has chosen to analyse the situation in Italy. Italy is the country where the category of dependent self-employment is not only recognised and officially regulated (Ranci, 2012; Tealdi, 2012; Pinelli et al., 2017; Gramano and Gaudio, 2019), but also protected similarly to employment (Spasova et al., 2019, MISSOC, Italy, 2021). Understanding the principles of regulation is a fundamental background for suggesting improvements in Slovakia, as well as for identifying possibilities of measuring the extent of dependent self-employment not only in Slovakia, but also in other countries.

The dependent self-employment requires deeper analysis in the European Union, mostly because of inconsistency in general understanding of dependency/independency of selfemployment across the EU. There is no official definition of not only dependent selfemployment, but also dependent work (employment) in many EU countries (OECD, 2019; Supiot 2001; Pedersini, 2020). Although the European Commission has called for the standardization and harmonization of dependent self-employment regulation (Opinion of the European Economic and Social Committee, 2011), this has not happened to date. There are only a few EU member states that have undergone wild reforms of labour market regulations and not only recognise, but also protect the specific status of dependent self-employed persons 
(Eichhorst, et al., 2013; Garcia and Gonzales, 2012; Pinelli et al., 2017; Picot and Menéndez, 2019). One of these countries is Italy.

Because of the high level of recognition and social protection of dependent selfemployment, Italy can serve as a good practice example not only for Slovakia, but also for the other EU countries, in which dependent self-employment is not officially recognised. After adopting Jobs Act, dependent contractors become part of a community governed by special legal rules in Italy. Even more, they gain a relevant status also under the employment law. Regardless of the ongoing debate on the economic freedom of dependent contractors and whether it should be maintained or fully subsumed under labour law (and thus fully dependent on the employer), the author considers developments in Italian legislation on dependent selfemployment to be an example of good practice. The findings presented in the paper are an initial effort to understand the economic perceptions and legislative regulation of dependent entrepreneurs. The main shortcoming of the paper is the current impossibility to support the legislative developments in Italy with adequate quantitative data that would confirm not only the growing trend of economically dependent entrepreneurs, but also their statistical registrability. Despite this shortcoming, the author considers the systematic summarisation of the development of the protection of dependent self-employment on the example of Italy as a relevant added value to the current state of knowledge.

The topic of dependent self-employment requires deeper analysis and research in the future. The persistent inhomogeneity in the definitions of entrepreneur and employee has become an issue in the context of the new trends in labour market (Bozzon and Murgia, 2021; Karlsson, 2019). They include not only the status of dependent entrepreneurs per se, but also the status of platform-dependent entrepreneurs (Kuhn and Maleki, 2017; Cutolo and Kenney, 2019), autonomous wage earners (Ballon, 2019), and dependent contractors in connection with various aspects of gig economy (Cherry and Aloisi, 2016; Lobel, 2017; Daskalova et al., 2021). Understanding the new forms of work which are created as a consequence of changes in society requires deeper understanding of individual employment and its regulation, of an employee status and its protection, and of all situations that exist on the border between the standard employment and standard entrepreneurship.

Grant support: This paper was supported by the National Research Agency of Slovakia, project VEGA no. 1/0366/21 "Dependent Entrepreneurship in Slovakia - Reflection, Measurement and Perspectives" at the Faculty of Economics, Matej Bel University in Banská Bystrica, Slovakia. 


\section{References}

[1] Aloisi, A. (2018). 'With great power comes virtual freedom'. A review of the first Italian case holding that (food-delivery) platform workers are not employees. Comparative Labor Law\&Policy Journal, 2018.

[2] Ballon, J. (2019). The entrepreneur-salaried employee-associate: An autonomous wageearner or a dependent entrepreneur? Society and Business Review, 14(4), 415-430.

[3] Barancová, H., \& Schronk, R. (2018). Pracovné právo [Labour Law]. Bratislava, SK: Sprint, 2018.

[4] Boheim, R., \& Muehlberger, U. (2006). Dependent Forms of Self-employment in the UK: Identifying Workers on the Border between Employment and Self-employment. IZA Discussion Paper No. 1963, 2006. http://ftp.iza.org/dp1963.pdf.

[5] Borghi, P., \& Murgia, A. (2019). Between precariousness and freedom: the ambivalent condition of independent professionals in Italy. In Self-Employment as Precarious Work. Cheltenham, UK: Edward Elgar Publishing.

[6] Borghi, P., Mori, A., \& Semenza, R. (2018). Self-employed professionals in the European labour market. A comparison between Italy, Germany and the UK. Transfer: European Review of Labour and Research, 24(4), 405-419.

[7] Bozzon, R., \& Murgia, A. (2021). Work-family conflict in Europe. A focus on the heterogeneity of self-employment. Community, Work \& Family, 24(1), 93-113.

[8] Campos, N. F., Nugent, J. B., Campos, N. F., Grauwe, P., \& Ji, Y. (2018). The Dynamics of the Regulation of Labour in Developing and Developed Countries. The political economy of structural reforms in Europe, 75-91.

[9] Cherry, M. A., \& Aloisi, A. (2016). Dependent contractors in the gig economy: a comparative approach. The American University Law Review, 635, 1-57.

[10]Cutolo, D., \& Kenney, M. (2019). Platform-dependent entrepreneurs: power asymmetries, risks, and strategies in the platform economy. Academy of Management Perspectives, $35(4), 1-48$.

[11]Daskalova, V., McCrystal, S., \& Wakui, M. (2021). Labour protection for non-employees: how the gig economy revives old problems and challenges existing solutions. In Platform Economy Puzzles. Cheltenham, UK: Edward Elgar Publishing.

[12]Del Conte, M., \& Gramano, E. (2017). Looking to the other side of the bench: The new legal status of independent contractors under the Italian legal system. Comparative Labor Law \& Policy Journal, 39, 579. 
[13] Dvouletý, O. (2017). Does the self-employment policy reduce unemployment and increase employment? Empirical evidence from the Czech regions. Central European Journal of Public Policy, 11(2), 11-22.

[14]Eichhorst, W. et al. (2013). Social protection rights of economically dependent selfemployed workers. Study of Policy Department, Economic and Scientific Policy.

[15]Eichhorst, W., \& Marx, P. (Eds.). (2015). Non-standard employment in post-industrial labour markets: An occupational perspective. Cheltenham, UK: Edward Elgar Publishing.

[16] Garcia, C. A., \& Gonzáles, C. N. (2012). The Regulation of Economically Dependent Selfemployed Work in Spain: A Critical Analysis and a Comparison with Italy. E-Journal of International and Comparative Labour Studies, 1(1-2), 117-133.

[17] Garnero, A. (2018). The dog that barks doesn't bite: coverage and compliance of sectoral minimum wages in Italy. IZA Journal of Labor Policy, 7(1), 1-24.

[18] Gilli, A., Ungaro, A. R., \& Marrone, A. (2015). The Italian White Paper for International Security and Defence. The RUSI Journal, 160(6), 34-41.

[19] Giraud, O., \& Lechevalier, A. (2018). The grey zone and labour market dynamics in Germany: new regulations and new ways of using employment categories. Selfemployment and traineeships. Transfer: European Review of Labour and Research, 24(3), 317-336.

[20]Gramano, E., \& Gaudio, G. (2019). 'New trade union strategies for new forms of employment': Focus on Italy. European Labour Law Journal, 10(3), 240-253.

[21] ILO (2010). Labour inspection in Europe. Geneva, Ch: International Labor Organisation.

[22] Karlsson, J. C. (2019). Job Quality in an Era of Flexibility. Experiences in a European Context. Nordic Journal of Working Life Studies, 9(3), 87-90.

[23] Knapková, M. (2017). Traditional and new forms of work - taxonomy of work. Economic theory and practice 2017 : proceedings of the Faculty of Economics of Matej Bel University in Banská Bystrica, 242-254. http://www.ef.umb.sk/ef/UploadFolder/1522/subory/ETAP\%202017_proceedings.pdf.

[24]Kuhn, K. M., \& Maleki, A. (2017). Micro-entrepreneurs, dependent contractors, and instaserfs: Understanding online labor platform workforces. Academy of Management Perspectives, 31(3), 183-200.

[25]Lassandari, A. (2019). Oltre la" grande dicotomia"? La povertà tra subordinazione e autonomia. [Okrem „,vel'kej dichotómie“"? Chudoba medzi podriadenost'ou a autonómiou]. Lavoro e diritto, 33(1), 81-102. 
[26] Lobel, O. (2017). The gig economy \& the future of employment and labor law. San Diego Legal Studies Paper No. 16-223.

[27]Ludera-Ruszel, A. (2017). Dependent Self-Employment in the Light of the Constitutional Principle of Work Protection. Roczniki Nauk Prawnych, 27(1EV), 41-57.

[28] Mariotti, I., \& Akhavan, M. (2019). Il coworking in Italia: localizzazione, performance, effetti sul contesto urbano. Giornale on-line dell'AISRe, 9(3), 107.

[29] Meliciani, V., \& Radicchia, D. (2005). Rendimenti dell'investimento in capitale umano in Italia: il ruolo dei canali d'ingresso nel mondo del lavoro. [Returns on investment in human capital in Italy: the role of entry channels into the world of work] In E. Mandrone \& D. Radicchia (Eds) Monografie sul Mercato del lavoro e le politiche per l'impieg. ISFOL, 13.

[30] MISSOC (Mutual Information System on Social Protection). (2021). Social protection for the self-employed. Italy. January 2021. https://www.missoc.org/documents/selfemployed/2021_01/self_2101_it_en.pdf

[31]Muehlberger, U. (2007). Dependent Self-employment: Workers on the Border between Employment and Self-employment. Houndmills, UK: Palgrave Macmillan.

[32] Nikulin, D. (2021). The determinants of false self-employment: A survey of Polish enterprises. Eastern European Economics, 59(1), 70-81.

[33] OECD (2019). OECD Employment Outlook 2019: The Future of Work. Paris, FR: OECD Publishing. 2019. https://www.oecd.org/employment/Employment-Outlook-2019Highlight-EN.pdf

[34] Opinion of the European Economic and Social Committee (2011). Opinion on 'New trends in self-employed work: the specific case of economically dependent self-employed work' (own-initiative opinion). https://eurlex.europa.eu/LexUriServ/LexUriServ.do?uri=OJ:C:2011:018:0044:0052:EN:PDF

[35] Pallini, M. (2019). Towards a new notion of subordination in Italian Labour Law?. Italian Labour Law e-Journal, 12(1), 1-24.

[36]Pedaci, M., Raspanti, D., \& Burroni, L. (2017). Autonomous, atypical, hybrid forms of employment: Aspects of social protection in Italy. National report (No. 10). WSI Study.

[37]Pedersini, R. (2020). Italy: Latest developments in working life Q4 2019. https://www.eurofound.europa.eu/publications/article/2020/italy-latest-developments-inworking-life-q4-2019

[38] Perulli, A. (2020). The legal and jurisprudential evolution of the notion of employee. European Labour Law Journal, 11(2), 117-130. 
[39]Picot, G., \& Menéndez, I. (2019). Political parties and non-standard employment: an analysis of France, Germany, Italy and Spain. Socio-Economic Review, 17(4), 899-919.

[40] Pinelli, D., Torre, R., Pace, L., Cassio, L., \& Arpaia, A. (2017). The recent reform of the labour market in Italy: A review. European Economy-Discussion Papers 2015-, (072). https://ec.europa.eu/info/sites/default/files/economy-finance/dp072_en.pdf

[41] Ranci, C. (2012). Partite Iva. Il lavoro autonomo nella crisi italiana [VAT numbers. Selfemployment in the Italian crisis]. Milano, IT: Il Mulino, 2012. ISBN 978-88-15-23829-0.

[42] Raitano, M. (2018). Italy: Para-subordinate workers and their social protection. In The Future of Social Protection: What Works for Non-standard Workers? Paris, FR: OECD Publishing.

[43]Razzolini, O. (2021). Organizzazione e azione collettiva nei lavori autonomi. Social Policies, 8(1), 49-73.

[44]Riesco-Sanz, A. (2019). Self-employment and the transformation of employment relationships in Europe. In A. Serrano-Pascual \& M. Jepsen (Eds) The deconstruction of employment as a political question (pp. 149-178). Cham, UK: Palgrave Macmillan.

[45] Seghezzi, F., \& Tiraboschi, M. (2018). Italy's industry 4.0 plan: an analysis from a labour law perspective. E-journal of international and comparative labour studies, 7(1), 1-29.

[46] Spasova, S., \& Wilkens, M. (2018). The social situation of the self-employed in Europe: labour market issues and social protection. In B. Vanhercke, S. Sabato \& D. Bouget (Eds) Social Policy in the European Union: State of Play (pp. 97-116). Brusells, BE: ETUI.

[47] Spasova, S., Bouget, D., Ghailani, D., \& Vanhercke, B. (2019). Self-employment and social protection: understanding variations between welfare regimes. Journal of Poverty and Social Justice, 27(2), 157-175.

[48] Supiot, A. (2001). Beyond Employment. Changes in Work and the Future of Labour Law in Europe. Paris, FR: Oxford University Press

[49] Tackling Dependent and Bogus Self-Employment. (2016). Discussion Note prepared for Workshop 3, Improving social rights and working conditions for atypical workers. Workshop, Ljubljana, Slovenia, 26 and 27 January 2016. https://fiaactors.com/fileadmin/user_upload/News/Documents/2016/January/FINAL-DiscussionNote-Ljubljana.pdf

[50] Tealdi, C. (2012). Typical and atypical employment contracts: the case of Italy. Munich, DE: University Library of Munich.

[51]Williams, C. C., \& Horodnic, I. A. (2019). Dependent self-employment: Theory, practice and policy. Cheltenham, UK: Edward Elgar Publishing. 
[52] Act no. 81/2015 Job Act

Author's address: Ing. Mgr. Miroslava Knapková, PhD., Department of Economics, Faculty of Economics, Matej Bel University in Banská Bystrica, Slovakia, miroslava.knapkova@umb.sk 